\title{
Use of Recycled Polyethylene Terephthalate (PET) Fibers in Concrete Cylindrical Pipes
}

\author{
Sudhira De Silva and R.M.M.P. Rathnayaka
}

\begin{abstract}
Fabrication of the reinforcement cages of concrete pipes, using conventional reinforcement bars, require special bending, welding and placement procedures, which are quite timeconsuming. Use of fiber reinforced concrete produced with polyethylene terephthalate (PET) fiber in the manufacturing of concrete pipes would be a sustainable solution since PET fiber is an eco-friendly material. The objective of this study was to investigate the use of PET fibers as a replacement material in the steel reinforcement cages used in manufacturing reinforced concrete cylindrical pipes. It was observed that at a water-cement ratio of 0.3 the optimum compressive strength of $45.8 \mathrm{MPa}$ could be achieved by including $2 \%$ of PET fiber in the concrete mixture. Three different types of specimens; plain concrete, reinforced concrete and PET fiber concrete were cast and subjected to the three-edge bearing test. PET fiber reinforced concrete provided the optimum strength required for producing concrete cylindrical pipes. The PET-fiber concrete cylindrical pipe is an economical and sustainable alternative to the classically-reinforced-concrete cylindrical pipe.
\end{abstract}

Keywords: $\quad$ Recycled PET, Compressive strength, Cylindrical pipes, Three edge bearing test

\section{Introduction}

Cylindrical concrete pipes which are often strengthened with steel reinforcements are used in many applications such as in underground pipe networks which carry waste water and storm water and the construction of deep wells, soakage pits and culverts in roads [3]. Manufacturing the cage required for the reinforced concrete pipes, using conventional reinforcement bars requires special bending, welding and placement procedures, which are very time consuming. Steel-fiber concrete pipes were found to be an economical alternative to classically-reinforced-concrete pipes as they help to overcome the difficulties encountered in using ordinary steel reinforcements in pipe systems [3]. For example, steel fibers of standard sizes can simply be added to the panmixer of any concrete mixer as an aggregate or mineral admixture. Similar to ordinary plain concrete, steel-fiber concrete can also be produced in moulds using standard procedures.

However, the continuous exposure of steel fiber in the pipes to water may lead the steel fiber to corrode and might reduce the durability of the pipes [4]. When manufacturing steel fiber reinforced concrete, the concrete mixture is usually sprayed onto a gateway having a crosssectional area of $4 \mathrm{~m} \times 4 \mathrm{~m}$. However, this method is sometimes found to be unsatisfactory because steel fiber-reinforced concrete often blocks the sprayer if steel fiber and concrete have not been properly mixed. To overcome this problem, an alternative type of fiber such as recycled PET fiber which has been properly mixed and which is not vulnerable to corrosion is used.

Rapid technological developments have increased the use of PET materials in the manufacture of containers. Among these containers, PET bottles have become very popular as beverage containers. However, it has to be noted that these PET bottles are a major environmental hazard as they will not degrade easily. Therefore, research on alternative recycling methods of PET fibers has received much attention [5]. The objective of this study was to investigate the use of PET fibers to replace steel reinforcement cages used in conventional reinforced concrete cylindrical pipes.

Eng. (Dr.) Sudhira De Silva, Ph.D. (Saitama), M.Eng. (Saitama), PG Diploma (Strut), B.Sc. Eng. (Hons) (Moratuwa), C. Eng., MIE(SL), Senior Lecturer, Department of Civil and Environmental Engineering, Faculty of Engineering, University of Ruhuna.

Email:sudhira@cee.ruh.ac.lk

Eng. R.M.M.P. Rathnayaka, B.Sc. Eng. (Hons), AMIE (SL), Department of Civil and Environmental Engineering, Faculty of Engineering, University of Ruhuna.

Email:madushanpri@gmail.com 


\section{Methodology}

\section{$2.1 \quad$ PET Fiber Material}

Beira Enviro Solutions (Pvt.) Ltd, Horana, Sri Lanka provided the PET fibers (Figure 1) required for the study. These PET fibers were added to the concrete mixture (in the proportions of $0 \%, 1 \%, 2 \%$ and $3 \%$ of total volume), without replacing any material in the typical concrete mixture. Each PET fiber addition was done for two water cement ratios: 0.3 and 0.45 . The average diameter and the length of the PET fiber were $0.7 \mathrm{~mm}$ and $50 \mathrm{~mm}$ respectively.

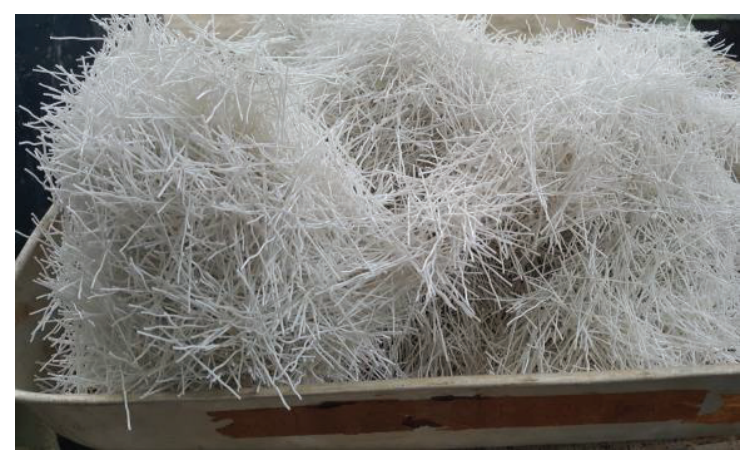

Figure 1 - PET fiber used in the study

\subsection{Experimental Procedure}

\subsubsection{Compressive Strength}

Concrete cubes, $150 \mathrm{~mm} \times 150 \mathrm{~mm} \times 150 \mathrm{~mm}$ in size, were cast according to BS 1881-108 (1988) and cured until the test date as described in BS 1881-111(1988). Mixing of concrete was in accordance with the guidelines provided in BS 5328 (1997). Rheobuild 1000 (high-range waterreducing admixture) was added to the concrete mix to ensure a workable mixture. A concrete compression testing machine was used to crush the concrete cubes (Figure 2(a)) at the age of 3, $7,14,21$, and 28 days to determine their respective compressive strengths.
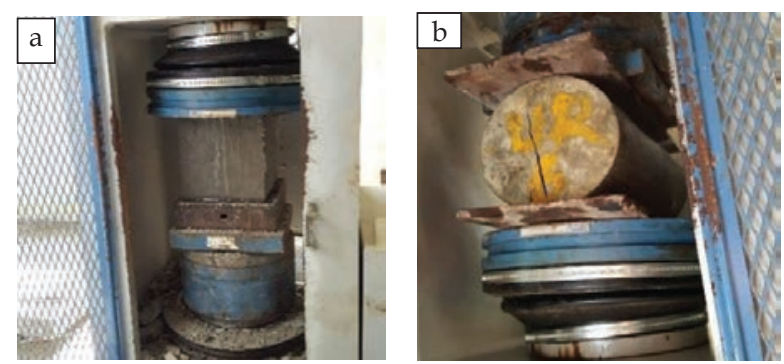

Figure 2 - Testing of specimens: (a) compressive strength test, (b) split tensile strength test

\subsubsection{Tensile Strength}

Three cylindrical specimens of standard size $150 \mathrm{~mm}$ in diameter and $300 \mathrm{~mm}$ in height were cast as described in BS 1881:144 (1988). Tensile strength of the concrete was determined by testing these standard cylinders. Split tensile strength of each specimen was measured by using a compression testing machine (Figure 2 (b)).

\subsubsection{Slump Test}

Slump of the concrete was evaluated at the laboratory for each mixture based on requirements given in BS 1881-102:1983. Slump was maintained at $80 \mathrm{~mm}$ to obtain a workable mixture.

\subsubsection{Load Test}

Cylindrical concrete pipes $0.5 \mathrm{~m}$ long (with an inner diameter of $0.3 \mathrm{~m}$ and a thickness of 100 $\mathrm{mm}$ ) were cast using three different types of concrete mixtures: plain concrete, reinforced concrete and fiber reinforced concrete. Two cylindrical pipes were cast using each mixture. The composition of each type of cylindrical pipe is presented in Table 1. Figures 3(a) to 3(d) show the steps involved in casting the cylindrical pipes. The fiber reinforced cylindrical pipe was cast using the concrete mixture (with a water cement ratio of 0.3 and $2 \%$ of PET fiber), which gave optimum values for the compressive strength, slump and tensile strength. Cylinders were cured for 30 days and their strengths were tested at the age of 30 days.

Testing of cylindrical pipes was performed in accordance with BS 5911 Part 100 (1988) using a Servo Control Static \& Dynamic Actuator and a Hydraulic Pumping System.Three edge bearing tests was conducted to measure the proof load of each cylindrical pipe. Using the proof load measured, the ultimate load for each cylindrical pipe was calculated. According to BS 5911-Part 100 (1988), proof load is the line load that a concrete pipe can sustain as an external load without developing $0.25 \mathrm{~mm}$ wide or $300 \mathrm{~mm}$ long cracks during the three edge bearing test. The ultimate load was determined by multiplying the proof load by 1.5. A grid of 50 $\mathrm{mm} \times 50 \mathrm{~mm}$ was drawn on the surface of the cylindrical pipe in order to observe the propagation of the cracks. The crack width was measured during the experiments using a filler gauge. The schematic diagram of the test apparatus and a pictorial view of the load test 
done on the cylindrical pipes are shown in Figures 4(a) and 4(b) respectively.
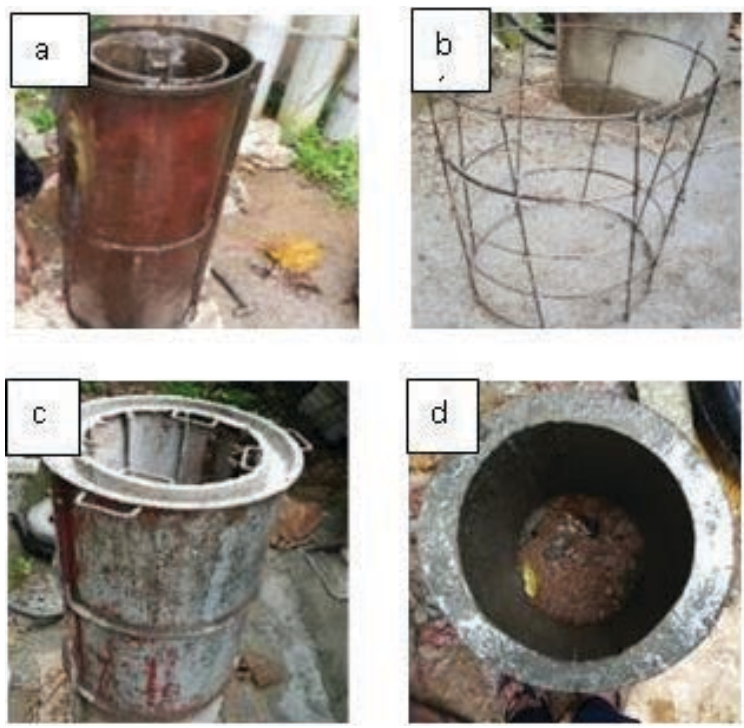

Figure 3 - Steps involved in casting the cylindrical pipes: (a) assembling of the mould, (b) steel reinforcement cage, (c) concreting, (d) curing

Table 1 - Test parameters of the cylindrical pipes

\begin{tabular}{|l|c|c|}
\hline $\begin{array}{c}\text { Specimen } \\
\text { type }\end{array}$ & $\begin{array}{c}\text { Amount of steel } \\
\text { reinforcement }\end{array}$ & $\begin{array}{c}\text { PET } \\
\text { fibers } \\
\text { (\% of total } \\
\text { volume) }\end{array}$ \\
\hline $\begin{array}{l}\text { Plain } \\
\text { concrete }\end{array}$ & N/A & 0 \\
\hline $\begin{array}{l}\text { Reinforced } \\
\text { concrete }\end{array}$ & $\begin{array}{c}6 \text { mm mild steel } \\
\text { mesh at } 120 \mathrm{~mm} \\
\text { c/c spacing }\end{array}$ & 0 \\
\hline $\begin{array}{l}\text { Fiber } \\
\text { reinforced } \\
\text { concrete }\end{array}$ & N/A & 2 \\
\hline
\end{tabular}

\section{Results and Discussion}

\subsection{Variation of Compressive Strength with PET Fiber Content}

The variation of compressive strength of PET fiber reinforced concrete with the age of the specimens for different percentages of fiber is shown in Figure 5. It can be observed that during the latter stages of ageing, and for a water cement ratio of 0.3 , fiber reinforced concrete behaves similar to normal concrete as far as compressive strength is concerned. The compressive strength of the fiber reinforced concrete that was made using a water cement ratio of 0.45 was lower than that of the control specimen.

Table 2 shows the percentage reduction of 28 day compressive strength with increasing percentage of fiber content for water cement ratios of 0.45 and 0.30 . It can be seen that in comparison to the control specimen there is a $42.35 \%$ reduction in the compressive strength after 28 days when $1 \%$ fiber by volume is added at a water cement ratio of 0.45 . However, at a water cement ratio of 0.3 , the reduction in the 28 day compressive strength is only $11.29 \%$ for $1 \%$ of fiber added by volume.

In 2007, Ochi et al. [1] conducted a uniaxial compression test and identified that at a 0.55 water cement ratio, the compressive strength of PET fiber reinforced concrete increases as the percentage fiber content is increased up to $1 \%$ (Percentage improvement in the compressive strength is $5.98 \%$ ). From this study, it is revealed that the compressive strength of fiber reinforced concrete decreases as the fiber content is increased beyond $1 \%$.

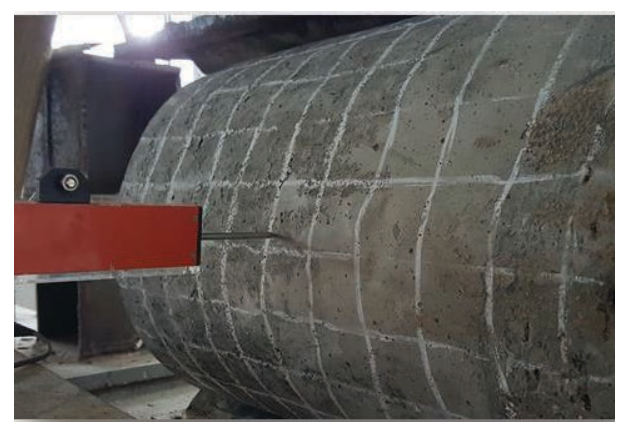

Figure 4(b) - Load test and the identification of crack propagation

Table 2 - Reduction of compressive strength (\%) with fiber percentage for a water cement ratios of 0.45 and 0.3

\begin{tabular}{|c|c|c|}
\hline \multirow{2}{*}{$\begin{array}{l}\text { Fiber } \\
(\%)\end{array}$} & \multicolumn{2}{|c|}{$\begin{array}{c}\text { Compressive strength reduction } \\
\text { compared to control specimen (\%) }\end{array}$} \\
\cline { 2 - 3 } & $\begin{array}{c}\text { Water-cement } \\
\text { ratio of } 0.45\end{array}$ & $\begin{array}{c}\text { Water-cement } \\
\text { ratio of } 0.30\end{array}$ \\
\hline 1 & 42.35 & 11.29 \\
\hline 2 & 42.14 & 8.92 \\
\hline 3 & 37.61 & 11.12 \\
\hline
\end{tabular}




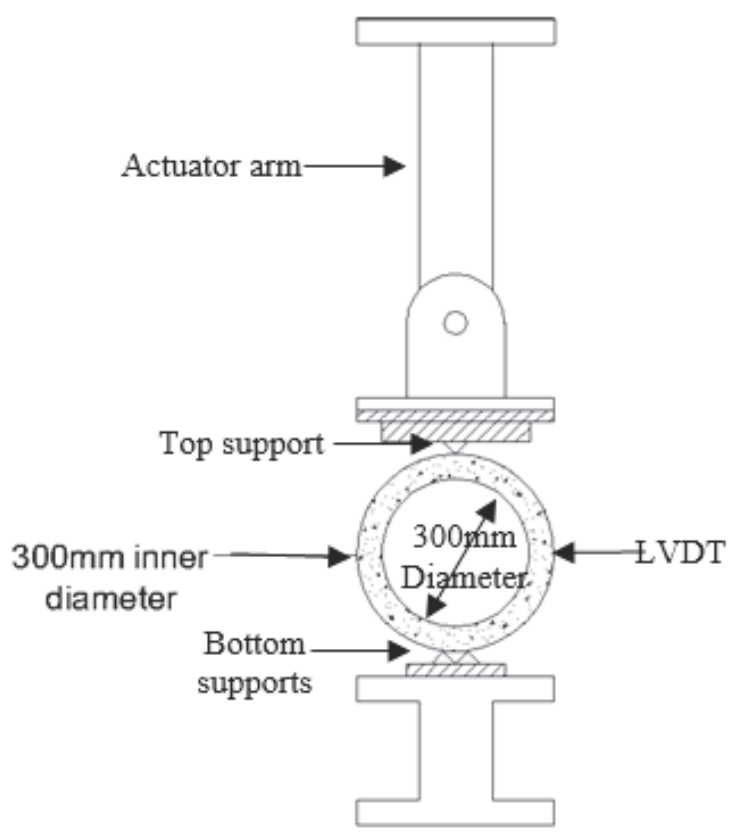

Front view

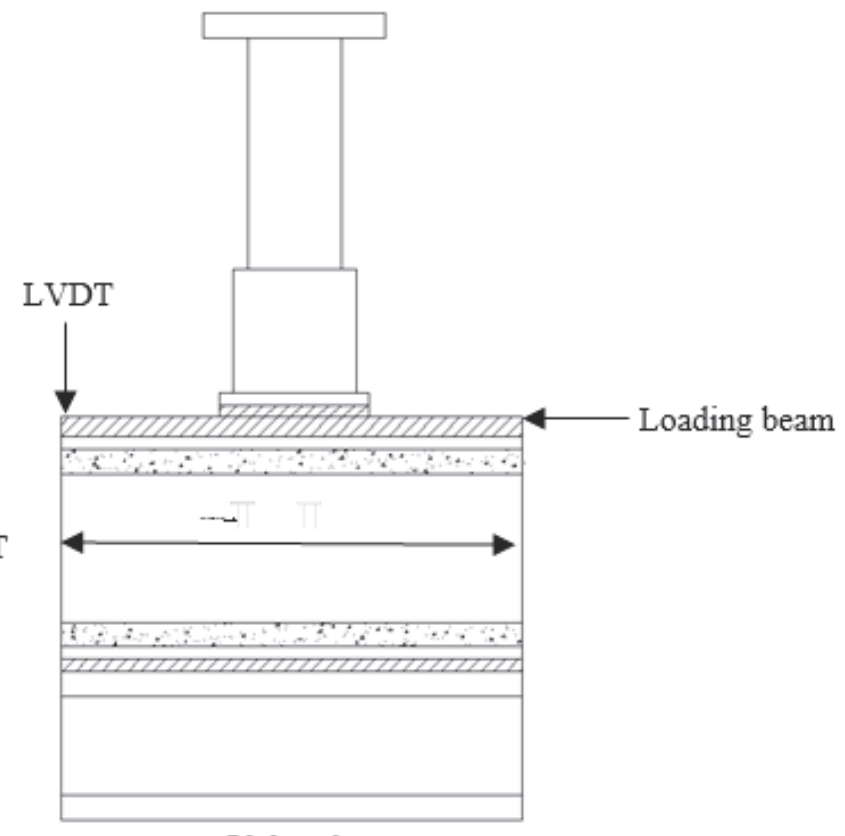

Side view

Figure 4(a) - Schematic diagram of the test apparatus

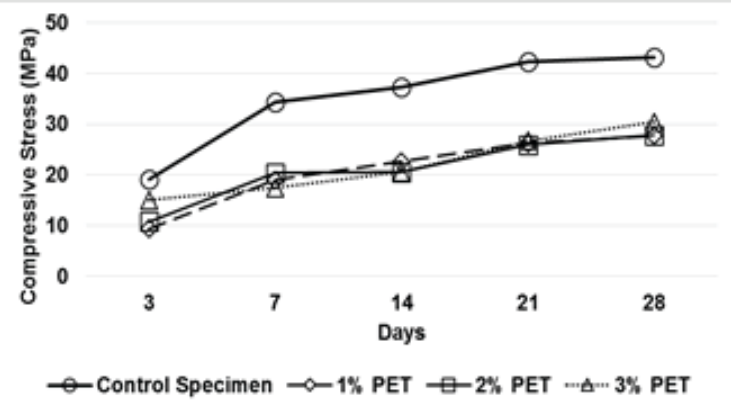

(a)

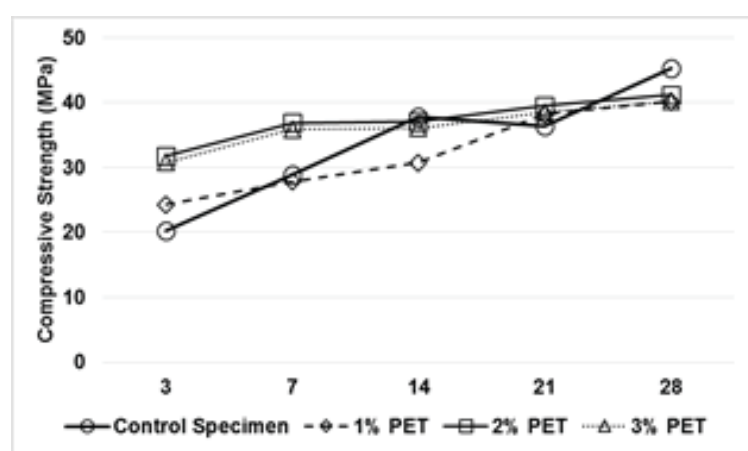

(b)

Figure 5 - Variation of compressive strength: (a) water cement ratio 0.45 , (b) water cement ratio 0.30

\subsection{Variation of Tensile Strength with PET Fiber Content}

As can be seen in Figure 6, for water cement ratios of 0.3 and 0.45 , tensile strength ( 28 day) of fiber reinforced concrete increases with fiber content. Specimens with a water cement ratio of 0.3 exhibit tensile strengths higher than those obtained for a water cement ratio of 0.45 . Table 3 shows the percentage improvement in tensile strength of concrete compared to the control specimen.

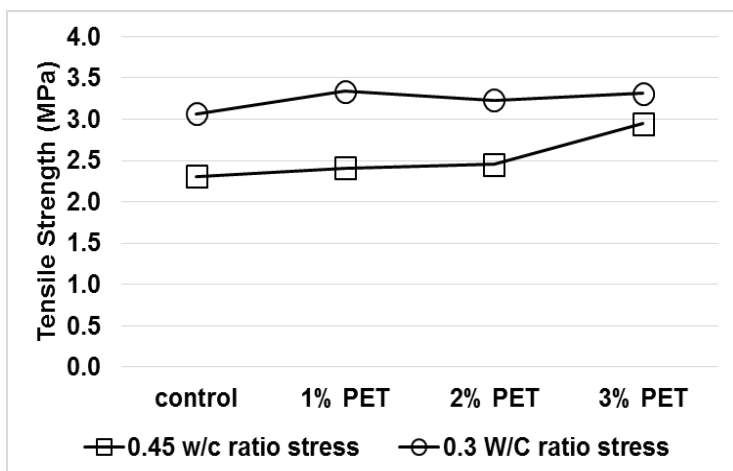

Figure 6 - Variation of tensile strength with fiber content for water cement ratios of 0.3 and 0.45

The inclusion of PET fiber improved the tensile capacity and showed that the concrete has the ability to absorb energy in the post-cracking stage due to the bridging action imparted by fibers during cracking. Sandaruwani et al., (2012) [4] identified that the tensile strength of concrete can be improved by increasing the fiber content up to $2 \%$ and that it will start to decrease as the percentage fiber content is increased beyond 2\%. Furthermore, in the study done by Marthong (2015), it has been observed that the inclusion of more than $1.0 \%$ 
PET fiber can cause the tensile strength of concrete to decrease.

Table 3 - Improvement in the tensile strength

\begin{tabular}{|c|c|c|}
\hline \multirow{2}{*}{$\begin{array}{l}\text { Fiber } \\
(\%)\end{array}$} & \multicolumn{2}{|l|}{$\begin{array}{l}\text { Improvement in the tensile strength } \\
\text { compared to control specimen }(\%)\end{array}$} \\
\cline { 2 - 3 } & $\begin{array}{l}\text { Water-cement } \\
\text { ratio of } 0.45\end{array}$ & $\begin{array}{l}\text { Water-cement } \\
\text { ratio of } 0.30\end{array}$ \\
\hline 1 & 104.25 & 108.23 \\
\hline 2 & 105.81 & 105.10 \\
\hline 3 & 121.72 & 107.54 \\
\hline
\end{tabular}

\subsection{Variation of Slump with PET Fiber Content}

Figure 7 shows the variation of slump with the fiber content. The slump of the concrete mixture with a water cement ratio of 0.45 is higher than that of concrete with a water cement ratio of 0.3 . There is a reduction in the slump as the fiber content is increased. As an example, at a water cement ratio of 0.3 and a PET fiber content of $3 \%$, the slump is $45 \mathrm{~mm}$.

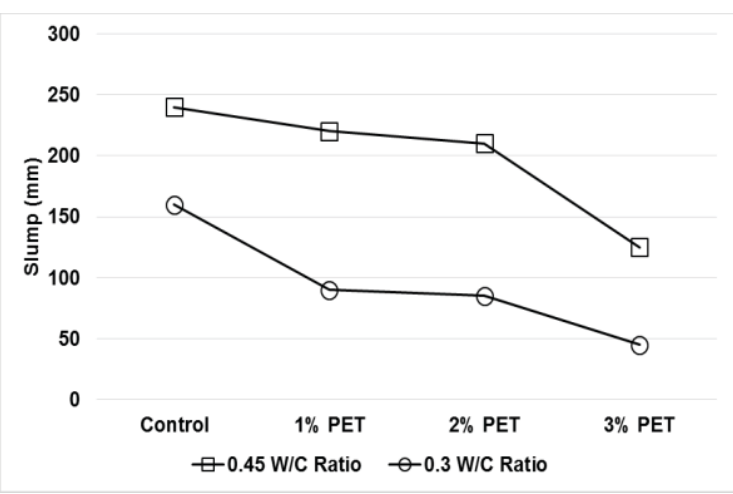

Figure 7 - Variation of slump with the fiber content

\subsection{Load Test}

The reinforced concrete cylindrical pipes show higher ultimate loads compared to plain concrete (refer load vs. deflection curve shown in Figure 9). It is found that PET fiber concrete performs better in the load test compared to steel reinforced concrete and plain concrete. There is a significant reduction in the crack length and crack width in fiber reinforced cylinders which satisfies the serviceability criteria of many civil engineering applications.

Plain concrete cylindrical pipes do not comply with BS 5911 Part 100 requirements in respect of ultimate load (Figure 9). Both reinforced concrete pipes and fiber reinforced pipes withstand loads greater than that specified in BS 5911 Part 100 (Figure 9).
Compared to the results of the study done by Haktanir (2007) on the performance of steelfiber reinforced concrete when used as a material in concrete cylindrical pipes, the results of the current study show a significant improvement in the ultimate load and a reduction in the width and length of the crack (Table 4). However, like steel fiber reinforced concrete, PET fiber reinforced concrete is also not subject to corrosion which will be a significant advantage for many of the applications in the field. These cylindrical pipes can be used safely in many applications where they have to be in contact with ground water that has different types of contaminated ions. Therefore, the use of PET fiber concrete cylindrical pipes will solve most of the issues that arise in the construction field.
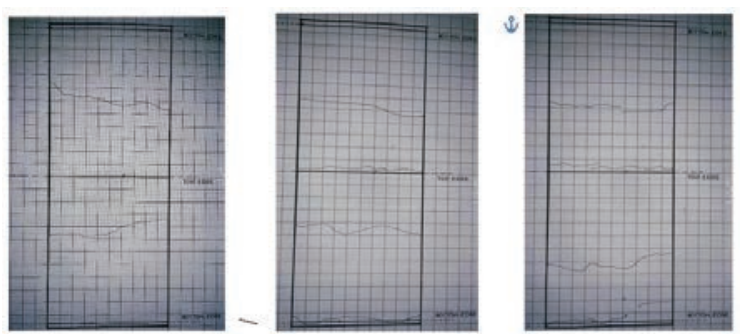

Figure 8 - Crack patterns (a) Plain concrete, (b) Reinforced concrete, (c) Fiber reinforced concrete

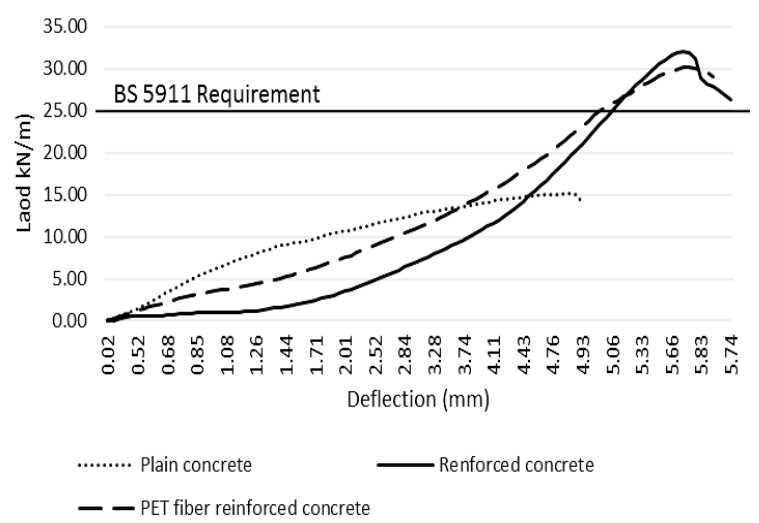

Figure 9 - Load vs deflection curve of cylindrical pipes

Table 4 - Crack width of pipes

\begin{tabular}{|l|c|c|}
\hline \multirow{2}{*}{\multicolumn{1}{|c|}{ Specimen }} & \multicolumn{2}{|c|}{ Crack width (mm) } \\
\cline { 2 - 3 } & $\begin{array}{c}\text { Current } \\
\text { study }\end{array}$ & $\begin{array}{c}\text { Haktanir et } \\
\text { al.,(2007) }\end{array}$ \\
\hline Plain concrete pipe & 0.25 & 1.50 \\
\hline $\begin{array}{l}\text { Reinforced concrete } \\
\text { pipe }\end{array}$ & 0.15 & 0.22 \\
\hline $\begin{array}{l}\text { Fiber reinforced } \\
\text { concrete pipes }\end{array}$ & 0.05 & 0.03 \\
\hline
\end{tabular}




\subsection{Cost and Weight Analysis}

The high cost of materials and labour, scarcity of building materials etc., have made cost to be one of the governing parameters in the construction industry. The type of cylindrical pipe proposed is used especially in domestic applications such as soakage pits, deep wells, irrigation systems etc. By comparing the manufacturing cost of the normal reinforced concrete cylindrical pipe and that of the PET fiber reinforced concrete pipe (Table 5), it is revealed that the cost per $0.5 \mathrm{~m}$ of pipe (inner diameter of $0.3 \mathrm{~m}$ ) can be reduced by around 310.00 LKR by using PET fiber reinforced concrete pipes making the use of these pipes financially beneficial.

Table 5 - Cost comparison of cylindrical pipes and PET fiber reinforced pipes

\begin{tabular}{|l|c|c|}
\hline & $\begin{array}{c}\text { Typical 3' } \\
\text { cylindrical pipe } \\
\text { avg. cost (LKR) }\end{array}$ & $\begin{array}{c}\text { PET fiber } \\
\text { reinforced } \\
\text { pipe avg. cost } \\
\text { (LKR) }\end{array}$ \\
\hline Casting cost & 200.00 & 200.00 \\
\hline Steel rebar & 500.00 & N/A \\
\hline PET fiber & N/A & 150.00 \\
\hline Concrete & 800.00 & 800.00 \\
\hline Plasticisers & N/A & 40.50 \\
\hline Total & 1500.00 & 1190.50 \\
\hline
\end{tabular}

The self-weight of the pipes can also be reduced by using PET fiber reinforced concrete in place of normal reinforced concrete as shown in Table 6. From the average values obtained from the three samples, it can be seen that compared to reinforced concrete pipes, PET fiber reinforced concrete pipes give a weight reduction of $15.5 \%$. This weight reduction enables less manpower, simpler machinery and easier handling.

Table 6 - Weight comparison between cylindrical pipes and fiber reinforced pipes

\begin{tabular}{|l|c|c|c|}
\hline Sample & $\begin{array}{c}\text { Reinforced } \\
\text { concrete } \\
\text { pipe }(\mathrm{kg})\end{array}$ & $\begin{array}{c}\text { Fibre } \\
\text { reinforced } \\
\text { pipe (kg) }\end{array}$ & $\begin{array}{c}\text { Weight } \\
\text { reduction } \\
(\%)\end{array}$ \\
\hline Sample 1 & 55.68 & 47.54 & 14.61 \\
\hline Sample 2 & 54.25 & 45.84 & 15.5 \\
\hline Sample 3 & 56.72 & 47.42 & 16.4 \\
\hline
\end{tabular}

\section{Conclusions}

An experimental study was done to compare PET fiber reinforced concrete pipes and normal concrete cylindrical pipes. Based on the results of this study, the following conclusions could be made:

PET reinforced concrete cylindrical pipes perform better than reinforced concrete cylindrical pipes. They satisfy the BS 5911 requirements pertaining to the ultimate load and showed smaller crack widths at service loads.

Furthermore, the three-edge bearing tests done on the cylindrical pipes showed that PET fibers have the ability to absorb energy in the postcracking state due to the bridging action imparted by the fibers during cracking. Consequently, the crack width and the crack length of PET fiber reinforced concrete are lower compared to those of typical reinforced concrete. PET fibers can be used for manufacturing cylindrical pipes of considerable strength, low cost and low weight while providing a cleaner environment.

\section{Acknowledgement}

The authors would like to express their gratitude to the Faculty of Engineering for providing necessary financial support through the Faculty of Engineering Research Grant 2015 and the Department of Civil and Environmental Engineering, Faculty of Engineering, University of Ruhuna for the support provided to successfully carry out the research work. The authors also wish to thank Beira Enviro Solutions (Pvt.) Ltd. for supplying the recycled PET fibers and Lal Construction, Hapugala, Galle for the support provided in the preparation of the specimens.

\section{References}

1. Ochi, T., Okubo, S., and Fukui, K., 2007.

Development of recycled PET fiber and its application as concrete-reinforcing fiber. Cement \& Concrete Composites, 29(6), pp. 448-455.

2. Fernando Fraternali, Vincenzo Ciancia, Rosaria Chechile, Gianvittorio Rizzano, Luciano Feo, 2011 Experimental study of the termomechanical properties of recycled PET fiberreinforced concrete. Composite Structures , 93(9), pp 2368-2374.

3. Haktanir, T., Ari, K., Altun, F. and Karahan, O., 2007. A comparative experimental investigation of concrete, reinforced-concrete and steel-fibre concrete pipes under three-edge-bearing test. Construction and Building Materials, 21(8), pp.1702-1708. 
4. Kosa, K. and A. E. Naaman, A.E. (1990) "Corrosion of steel fiber reinforced concrete." Materials Journal, 87(1), pp 27-37.

5. Sung Bae Kim, Na Hyun Yi, Hyun Young Kim, Jang-Ho Jay Kim, Young-Chul Song, 2010. Material and structural performance evaluation of recycled PET fiber. Cement and concrete composites, 32(3), pp. 232-240.

6. Sandaruwini, A. H. W. E, Bandara, K. A. J. M. and De Silva, G. S. Y., Investigation on Mechanical Behavior of Concrete with Fibers Made of Recycled Materials, Proceedings of International Conference on Sustainable Built Environment (ICSBE-2012), 14-15 December 2012, paper no. SBE/12/81.

7. British Standards Institution (1988) BS 1881-108 Testing concrete. Method for making test cubes from fresh concrete. London: British Standards Institution.

8. British Standards Institution (1988) BS 1881-111 Testing concrete. Method of normal curing of test specimens $\left(20^{\circ} \mathrm{C}\right.$ method).London: British Standards Institution.

9. British Standards Institution (1997) BS 5328-2 Concrete. Methods for specifying concrete mixes. London: British Standards Institution. 